\title{
MERDE! TEACHINGS FROM RUSSIAN ART TO ORGANIZATIONAL LEARNING
}

\author{
Merde! 0 que a arte russa tem a ensinar à Aprendizagem Organizacional
}

\author{
Rodrigo Robinson* \\ Marcio Pascoal Cassandre**
}

\section{ABSTRACT}

Considering the human being in his entirety is to understand him as a spiritual being, who does not separate the existential from the instrumental, who finds and shapes the meanings of what he experiences in the action or while acting, can be a path to more adequate responses to the present society (LINCOLN; GUBA, 2006). In this article, we relate concepts and practices in Russian art with Organizational Learning (OL). From Vygotsky's ideas on Double Stimulation and the method of Ascending from the Abstract to the Concrete, used in learning theories like the Cultural-Historical Activity Theory (CHAT), we sought to establish a connection between the potential of art to stimulate and develop man's learning as a spiritual being and OL. Art offers the possibility of awakening a spiritual force that can move man and "awaken" him to his role of agency, transforming his life and his reality. This relationship is established by bringing Vygotsky and Stanislavski together, and we use the method of the Russian playwriter to propose a draft method that considers art as medicine and a cure for organizations to understand the human being in his entirety and also for them to be constituted as spaces for development.

Keywords: Organizational Learning. Art. Spirituality.

\begin{abstract}
RESUMO
Considerar o ser humano em sua integralidade e entendê-lo como um ser espiritual, que não separa o existencial do instrumental e que encontra e molda os significados do que vive na ação, pode ser um caminho para repostas mais adequadas à sociedade atual (LINCOLN; GUBA, 2006). No presente artigo, relacionamos conceitos e práticas na arte russa com a Aprendizagem Organizacional (AO). A partir das ideias de Vygotsky em Estimulação Dupla e o Ascender do Abstrato para o Concreto, utilizadas em teorias da aprendizagem como a Teoria da Atividade Histórico-Cultural, procuramos relacionar o potencial da arte de estimular e desenvolver a aprendizagem do homem como ser espiritual com a AO. A arte tem a possibilidade de despertar uma força espiritual que pode mover o homem e "acordá-lo" para o seu papel de agência, de transformador de sua vida e de sua realidade. Esta relação se estabelece com a proximidade de Vygotsky e Stanislavski, e utilizamos o método do dramaturgo russo para propormos um esboço de método que considera a arte como remédio e cura para as organizações compreenderem o ser humano em sua integralidade e constituírem-se em espaços de desenvolvimento.
\end{abstract}

Palavras-chave: Aprendizagem organizacional. Arte. Espiritualidade.

\footnotetext{
* PhD student in Administration at the Universidade Estatual de Maringá (UEM). Master of Administration at the Universidade Estatual de Maringá (UEM). Email: rodrigorobin@hotmail.com. ORCID: 0000-0003-2768-7685

** Postdoc at the Danish School of Education at the Aarhus University. Professor of the Administration Department and the Post-Graduate Program in Administration at the Universidade Estadual de Maringá (UEM). E-mail: mpcassandre@uem.br. ORCID: 0000-0001-9415-4315
} 


\section{OPEN UP THE CURTAINS!}

W e think it is appropriate to name this article with that expression of French origin (Merde!), which for the actors and people involved with theater means "good luck" or "a good show". The story goes that at the time when people used carriages as a means of transport, the more carriages in front of the theater, the more manure from horses were left in the streets. Soon, people would come into the theater with their dirty shoes, making the amount of "shit" left in the doormats a synonym for full house.

We point out that emotions sometimes have a scent that most organizations are not willing to "feel". According to Campbell (2003), the suppression and denial of emotions is part of the process of rationalization, Puritan virtue and the Illuminist project that subordinates everything to Reason, Progress and Science. Organizations are, quintessentially, a place of vigilance and control, dominated by instrumental rationality and oriented towards efficiency, creating an unfavorable environment for emotions and learning to be experienced.

Although neglected for years, the theme of emotions has been approached from several perspectives. Initially confined to discussion ghettos, it has gained more and more space. Biologists, neurologists, psychologists, psychoanalysts, and even economists have elaborated on the subject. Although the philosophy of Plato and Descartes postulates antagonism between emotion and reason, emotions have increasingly been understood as a significant part of rational decision (VINCE; GABRIEL, 2011).

In the postulates of Organizational Studies (OE), the fundamental contribution of Organizational Learning (OL) lies in understanding emotions as a social construction, as being acquired and learned in collective experiences (HODDER, 2016; VINCE; GABRIEL, 2011).

We wrote this theoretical essay based on the exchange of experiences between teacher and student in the context of graduate studies in Administration. The first one, based on theoretical-empirical understandings of Organizational Learning, and the latter with the experience of those who, over the last decade, have dedicated themselves to the management of creative teams in corporate spaces: people with a clear artistic spirit, designers, advertisers, artists who seek to fit into the organizational environment and who, on a daily basis, negotiate with the demands that the market and the organizations impose on them, and who, nevertheless, emotionally engage with the fruit of their work, signify each stage of the process, suffering and delighting in it, imprinting their marks and being transformed as they develop it.

The present essay is written from the perspective of those who believe that man has the potential to transform his reality when inspired by a spiritual force that is inherent to him, but which can remain dormant throughout his life; from the perspective of those who understand that man, as a social and historical being, suffers the weight of the culture and structures of his time and context. Structures that have restraining power over his path and his trajectory, until the moment when this spiritual force awakens him to assume his role of

1. Throughout this article we are using 'he', 'him', 'his' herein as a gender-neutral pronoun, even though some people use the third person plural or the pairs 'she/he', 'her/him', 'hers/his'. 
agent, of protagonist of his own life, resignifying his relations and releasing his potential of transforming himself and the world around him.

It is in this respect that art can act as a stimulus, an inspiration and a method for the expansion of the human being, for the development of potentialities, for a more integral life, which comprises the totality of being. Art can be the medicine and the cure. For Weber (1998), the rationalization and bureaucratization of life has "caged" the subject; Adorno (1999) sees the Cultural Industry as an impediment to the formation of autonomous, independent individuals capable of judging and deciding consciously, and states that art has the power to liberate man from these moorings, granting him autonomy and humanity.

Our goal in this article is to relate Stanislavski's method to OL, seeking approaches that may contribute to the expansion of knowledge and the internalization of learning. We looked for ways to do so by establishing connections between the Russians Vygotsky, a theorist of human development and learning, an interested scholar of the arts as a model for teaching-learning (WEDEKIN; ZANELLA, 2016), and Stanislavski, his contemporary, who, with his method, revolutionized theater and is a reference, to this day, when one seeks a deeper, more intense art, marked by the individuality and emotion of being, as opposed to the emptiness of the cultural industry. Some learning theories, such as the Activity Theory (ENGESTRÖM, 1999; COLE; ENGESTRÖM, 2001; SANNINO, 2011; QUEROL; CASSANDRE; BULGACOV, 2014) have used Vygotskian concepts such as the Double Stimulation and the method of Ascending from the Abstract to the Concrete. It is by considering such concepts that we begin this connection, an exercise of reflection, to subsequently offer a first proposal of a method for learning with the help of Stanislavski's system.

Some efforts have also been made to use art in OL. Vera and Crossan (2004) bring improvisation theater and improvisation in companies together and highlight some important aspects so that good results can be obtained. The first one is recognizing the uncertainty of success in an improvisation. The second one is that in theater, for a good improvisation, the emphasis must be on the process, not the final outcome, which differentiates it from organizational interests. Finally, they point out aspects such as agreement, awareness and collaboration so that improvisation can bring good results. Pässilä and Oikarinen (2014) offer the idea of using theater techniques to create a polyphonic environment in which meanings and changes take place in a continuous collective learning experience. We also cite the relevant work by Daved Barry (2008), who makes a conceptual review of art, suggesting that the use of art concepts may represent a rupture in management. This author considers the idea of workers acting as Artists and modifying the organizations, an idea with which we align our discussion in this text.

This discussion is important for the organizational environment, since the theories of $\mathrm{OL}$ are still incipient when it comes to understanding the worker as an integral being and recognizing that neither the moment nor the result of learning can be controlled; and are even more reticent in terms of allowing this to happen as an initiative from the organization, because it presupposes flexibility and the acceptance that it is impossible to control everything. However, we see that by favoring that human beings develop as a spiritual being, and are allowed to create, leave their mark, even if it may be contrary to organizational objectives, this process may even bring an indispensable de-homogenization to the organization. Although there are no guarantees of success, growth and increment in the most positivist 
understanding of the term, it certainly opens space for differentiation, for relevance, for authenticity, for innovation, concepts that are so valued and often so distant from the reality of organizations.

We structured this article in three sections, in addition to the introduction: theoretical contributions, method proposal and conclusions. The titles are also inspired by theater expressions and we sought to make the meaning of this relationship explicit at the beginning of each section. In section two, we discussed how the different theories of OL have comprised the worker and in what points they have advanced in the sense of conceiving him as a spiritual being, capable of being the author of his history. In section three, we started to construct a proposal of a method for OL, trying to bring the ideas of Vygotsky and Stanislavski together. In section four, we draw the conclusions and suggest future directions for the continuity of this proposal.

\section{TABLE-READ}

"Table-read" is the expression used in theater for the first reading of the script in a joint way, in which each actor comes in contact with the lines of his role. In this section, we refer to the theoretical review on learning and work in organizations.

\subsection{UNHEALTHY ENVIRONMENT FOR LEARNING}

When we think of OL, we want to consider it in its broader aspect, that is, in organizations inserted in a capitalist system of industrial production in a consumer society. It is in this context that labor relations take place, and it is under this logic of rationality, efficiency, specialization, utility that people are measured. This space of control and search for efficiency does not favor the elements that facilitate learning, so we consider it unhealthy. At a time when words such as hybrid, ambidextrous, liquid, multidisciplinary are becoming more frequent, it is important to rethink the way we see man in his organizations and his relationship with work.

Marx (1968) states that work is central to the life of man; it is the externalization of the being, it is the materialization of that which is essential, it is a way of expressing humanity, of manifesting that which is highly individual, transforming the world and providing the satisfaction of needs. For this reason, he regards the capitalist labor relation as alienating, as it separates, by the process of specialization, the man from the fruit of his effort. According to this premise, man loses his relationship with the final product, because the latter does not belong to him, he only has his wage, because the wealth, the product, the value of what was produced does not belong to him. The product ceases to have use value and is replaced with exchange value.

In moving away from what he produces, man loses all the affective and emotional relationship he had with the product of his work, an experience that the artisans had with their creations and the artists still maintain. Fayga Ostrower, a renowned artist, teacher and thinker of the arts, regards this as a process of "desensitization of people" (OSTROWER, 
1981), arguing that we no longer perceive the productive process as a process of transformation.

\begin{abstract}
Man himself becomes a commodity, replaceable as soon as he gets out of the so-called productive cycle - of commodities, of course [...] But it turns out that the real human qualities - which are the achievements of man: creativity, imagination, courage, love, understanding, maturity, the very experience of life - cannot be commodities and cannot be replaced. They are qualities of growth and each one of us has to conquer them for ourselves. (OSTROWER, 1981 , p. 2 - our translation, emphasis added)
\end{abstract}

Besides the lack of relation with the product of the work, the control exerted on the organizational environment does not favor learning either. The false idea that one can control everything and the relation of production to time (production rate), which was established in the industrial revolution in search of greater productivity and efficiency, has created a locus of control and punishment. Foucault (2014) shows how this logic permeated organizations, not only "productive" organizations, but also schools, hospitals, subjecting and creating "docile bodies" so that they assimilate the system.

It is in this space that theories of organizational learning have been developed and, therefore, have a paradoxical characteristic. Weick and Westley (2004) present the antagonism of terms that constitute this expression; while organizing presupposes order, decreasing variety; learning involves disorganizing and increasing variety. In relation to this oxymoron, these authors propose a review on the understanding of the terms "organization" and "learning".

By accepting the organization as a culture, the paths to understand organizational learning open up. Just as culture presupposes identity, and it is transmitted to a group through language, artifacts and routines of action, so organizational learning is understood as a collective process that is deemed effective when assimilated and inserted into the structure of organizations (WEICK; WESTLEY, 2004). The contradictory nature of terms is for authors also the path to learning moments, which means that it is neither a matter of completely eliminating order nor of refuting any initiative that deviates from the norm. It is a question of flexibilizing technical rationality (WEBER, 2004) and allowing creativity to find its space; of allowing innovations to be incorporated while the organization keeps its cultural identity; of finding space in the routines so that moments of learning take place and enable resignification or change.

In the view of Bitencourt and Azevedo (2006), facilitating learning involves sensitizing, opening space to contradictions, to error, to multiple possibilities, to humor as ways of questioning that which is crystallized; of improvising as a way of experiencing new alternatives. Learning confronts the positivist view that tends to seek a unique and correct response. The paradox, the contradiction, the complexity, the multiplicity, the rupture are characteristics of this ambivalent juxtaposition that allows learning to occur.

The understanding of who learns in the organization, that is, whether learning occurs at the individual level or whether the organization learns, remains open in different approaches. However, there seems to be a tendency for most approaches to understand 
learning as a social, dialectical process. In the view of Antonello and Godoy (2011), research could pursue the idea that this process is interpersonal.

Gherardi (2007) conceives learning through active participation in the daily practices of the organization, a process that flows naturally, whether consciously or not, that runs through the organizational life, as part of human existence and involves man's capacity, pre-reflected, tacit knowledge, focused awareness and his subsidies, feelings and perceptions, situated in a historical and social context. The living knowledge built in the relationships and reflections necessary in moments of rupture.

According to Reckwitz (2002), Theories of Social Practice are seen as part of cultural theory, but new authors are distinguished from classical theories by the way they understand and explain action. The classical theories are based on the understanding of the homo economicus, that explains action on the basis of the purposes, intentions and individual interests, and the view of the homo social, that explains the action oriented by norms and collective values. The new theories consist of understanding action as a reconstruction of the symbolic structures of knowledge, which allow the subject to interpret the world and behave in a corresponding way; it is a joint, collective construction of shared symbolic cognitions and structures.

In the Theory of Practice, the social world is not constructed in the mind, neither in discourse nor in interactions, and social practice is envisaged as a routinized type of behavior and understanding, as patterns of understanding, of knowing and desiring. Practice as a way of doing and saying that appears in different places and times, held by different minds and bodies. The body as the locus of social practices, the mind as the place of the know-how to perform them; objects as bearers of particular meanings necessary for many practices; knowledge as collective, shared, deeply embedded in history, in culture, and expressed in specific ways of understanding the world. The routinization of discourses and structures guide the way the body behaves in the practices. The individual is regarded as the only one capable of interpreting the crossover of bodies and minds routinized by social practices (RECKWITZ, 2002).

The literature on OL has addressed two premises as opposites and competitors, a cognitive approach (individual learning) and a more participatory approach (collective approaches of practice). Elkjaer (2005) presents a third way that does not deny the role of cognition, but conceives organizations as social worlds in which learning happens through research experience in order to solve a problem, and through which knowledge is actually elaborated by reflection or by reflective thinking.

The third way proposes the understanding that thought is instrumental in the process of participatory learning and that learning has its place in the social process. It is an intuitive process that unites the individuality of the subject, his body and emotions, his past experiences and the environment in the action of seeking for a solution. Once the problem is solved, reflection allows the creation of relations between the experience and the solution, which produces knowledge.

When pointing to a third way, Elkjaer (2005) inspires us to reflect on the dialectics of organizational changes that include CHAT: a tradition that has its first generation in Vygotsky and that has advanced, with the contribution of other contemporary authors, to 
understandings more focused on the organizational environment. In this line, the understanding of development no longer refers to the positivist idea of the term and refers to the learning process and growth of the individual as he relates to his work, the artifacts, the context and the people around him.

Vygotsky (1978) inaugurates a new understanding of development and learning by arguing that the first occurs on two levels, the real and the potential. The real development would be the mental age, identified by what the child can accomplish alone; the potential development is what the child can accomplish with the help of other people, an adult as the teacher, for example. What is between the real and the potential is what he called the "Zone of Proximal Development (ZPD)", what will be learned, the potential, what will happen and not what has already been accomplished. Therefore, the child develops when faced with challenges that at first he cannot solve when challenged.

Backed by Vygotskian ideas, Veresov (2010) transposes these concepts into the experience of adulthood by conceptualizing Learning as the Real (which is natural of the individual) and Ideal (that which is cultural). For this author, it is in the interaction between the real and the ideal that learning, development, take place.

Another difference between Veresov's approach and Vygotsky's is the understanding that the process of learning and development happens in cultural-collective relations and not only in the cultural-individual level. A child learns the first words to communicate with adults, even before they have reflected or assimilated their meanings. In this sense, Veresov (2010) points out that learning, according to the CHAT, is a process that passes through social experience mediated by signs (meanings) and artifacts (tools).

Veresov (2010) points out that these processes start from a dramatic exchange experience between two or more people. The study cites Vygotsky by pointing out that in these moments, when the emotions arise, people can reflect on their postures, review their positions, and in fact change their minds in a development process.

One of CHAT's presuppositions is the centrality of the activity in the learning process. In the case of adults, work as the leading activity represents the socio-cultural notion of the group, that must be manifested by anyone who reaches the age or level of experience "expected" (group expectation) in a historically situated view (COLE; ENGESTRÖM, 2001).

Another important concept is that learning is mediated by artifacts, that is, objects are modified by human beings as a means of regulating their interactions, reacting to these objects in order to stimulate learning (COLE; ENGESTRÖM, 2001). In this line of reasoning, the idea of Vygotsky's Double Stimulation is another pillar of this approach. Double Stimulation consists of placing the person before a problem beyond his capacities: this would be the first stimulus; the second is to provide a neutral object (artifact) that can awaken in the individual an appropriation that allows him to develop and solve the initial problem (CASSANDRE; GODOI, 2013).

Vygotsky places the emotions in a prominent place in the process of learning and development, which confronts the predominant rationalist view in organizational environments. Not only considering emotions, but knowing how to deal with them seems to us a great challenge in the organizational space; on the other hand, it also represents the possi- 
bility of bringing understanding and experiences of personal and organizational development to other levels.

These interventionist approaches have taken the possibility of transformation, expansion, development of the human being as originating from the activity that is central to his life, i.e., work, seriously; and therefore, also located in the organizational environment. By understanding learning as a social process, as dialectic, collective, interactional, contextualized in time and space, experienced in practice, in daily living, which occurs in different ways, at different times, in different places, arising from paradoxes, contradictions, complexity, multiplicity and rupture, these approaches have sought to understand the human being in a more comprehensive way.

The wholeness of human beings includes his intellect, his body, his history, his emotions, and his spirituality. In our view, it is necessary to advance the understanding of the human being and the importance of facing him as an integral being, especially in his relationships and experiences in organizations. In the following sections we intend to lay the foundations of our understanding of man as a spiritual being and the possibility of art contributing as an artifact to the development of human potential in his main activity: work.

\subsection{THE SPIRITUAL BEING AND SPIRITUALITY}

In general, the practice and study of management has privileged analytical and easily quantifiable subjects, and has systematically avoided aspects related to emotions and spirituality (WADDOCK, 1999). This preference can be understood in light of the "Cartesian division" deeply ingrained in Western society: the separation between body, mind and spirit; between what cannot be known and the real; between objective and subjective; material and immaterial (WADDOCK, 1999).

OEs have made efforts to incorporate social aspects and a more complete understanding of the human experience in research on organizations. As for example, the idea of man reflected in the Parenthetic Man of Guerreiro Ramos (1984) and the idea of the Emotional Man of Flam (1990), and even the culturalist theories that understand man as an agent capable of social transformation (RECKWITZ, 2002). Thus, the comprehension of the integrality of the human being, of the inclusion of the emotions and of a spiritual possibility of extrapolating the rational and biological, still lacks conceptualization, especially when it comes to understanding man in organizations.

Organizational scholars have pointed to a future in which spirituality is portrayed and researched in organizations' studies more often. In this regard, Lincoln and Guba (2006, p. 190) assert: "We may be entering an era of greater spirituality within research efforts". They also point to the possibility of understanding and promoting a fully human existence. Peter Reason (1993), in turn, asserts that secular science is inadequate for our times and argues for the need to re-sacralize our experiences of ourselves and the world. It is in this context that we propose the understanding of man as a spiritual being who can live fully on the basis of his leading activity: work.

To lay the foundations of spirituality as we understand it, we need to revise something that was present in Martin Luther's understanding of the Protestant Reformation 
and which did not have the same impact on society as the consequences of the ascetic conduct of Calvinism. For this purpose, we return to Max Weber and his reading on the Spirit of Capitalism (WEBER, 2004). Weber points to Luther's understanding of vocation as a milestone for a change in man's relationship with work. According to the author, when translating the Bible, Luther re-signifies the word vocation (beruf), giving it the meaning of a life goal, a field in which to work (WEBER, 2004). In this sense, man is called by God to work. According to the reading of Weber (2004), this change allows the moral justification of worldly work, which, together with the idea of Calvin's ascetic conduct, would constitute the justification for the process of rationalization of society.

However, there is something in Luther's understanding of the vocation to work that has been forgotten and inspires us to rethink the role of spirituality in the practice and in understanding life in organizations. Weber (2004) points to Luther's monastic tradition and the understanding that prayer and work complement each other in the development of spirituality. Thus, the reformist understanding of work as a divine vocation means that work is part of the spiritual development, and therefore is "the outward expression of brotherly love" (WEBER, 2004, p. 7).

The spiritual being as we understand him, is the human being in his entirety. This encompasses his biology, body, mind, wants and emotions and his spirituality, intuition and consciousness. Ostrower (1981) claims that the spiritual is the dimension that goes beyond the biological; it is the essence of man. The spiritual has also been understood as the soul of the human being, the vital force of the individual, the energizing force (KAHNWEILER; OTTE, 1997).

We believe in the possibility of a deeper experience, infused with more meaning and passion, in organizations and in relation to work. This possibility involves the understanding of work as an expression of spirituality

If we want to create meaning in our own lives and want to help our students, clients, managers, create meaning and passion in their lives, then (my guess) we need to do much, much more to tap into their emotional and spiritual sides than the analytical approaches that dominant management education now allow. (WADDOCK, 1999, p. 342-343 - emphasis added)

Of course, the concepts presented in this section are still preliminary and inconclusive, and given the lack of references on spirituality in organizations, it becomes a broad field for the development of new research. Nevertheless, they seem to us sufficient to understand what we call spirituality. In the subsequent sections, we focus on the main purpose of this paper: to present a possibility of a method that brings the understandings of Vygotsky and Stanislavisky together, offering art as a process for the awakening of spirituality in the experience of Organizational Learning.

\subsection{ART AS STIMULUS TO AWAKEN THE CREATIVE SPIRIT}

As we mentioned in the introduction to this article, we believe that the individual can also be awakened to its role of agency, and thus be transformed, releasing his creative 
and transformative potential when touched in his spirituality. Understanding the individual in his entirety implies recognizing him as a spiritual being. It is in relation to this aspect that we intend to deepen the discussion, offering art as a possibility to instigate the individual to create ways to solve his problems and to develop while learning in organizations.

The creative potential of man is accomplished within his own productivity. Stimulated by the challenge of needs to be satisfied, tasks to be fulfilled in order to better survive, in his work man imagines solutions and creates them. Likewise, art would be characterized as work, in the sense of being useful for the survival of man. More than useful, however, art affects the human essence of man; adding new dimensions to existence, it transcends the biological being to characterize, in man, a spiritual being. (OSTROWER, 1981 , p. 1 - our translation, emphasis added)

The sense of spiritual being refers to the idea that the integral human being is more than physical, biological; he has an essence. Both the artist and the spectator somehow touch each other, or let themselves be touched in the depths of their beings and realize they have changed, they have been transformed. Art has the potential to reach the human essence, to surpass the physical, the biological and touch the wholeness of beings, and when it does, it creates new things, it changes man, adds new dimensions, affects the human essence. According to Stanislavski, the actor's work is directly related to the "complete concentration of his entire physical and spiritual nature" (GUINSBURG, 2008, p. 312). Art also has a practical use, since such as the interventionist perspectives of learning, it occurs in practice, in the production of solutions that allow man to lead better lives.

In view of its broader aspect, art has the potential to stimulate the subject to ask questions, to find contradictions, to deal with the complexity and multiplicity of experiences and to enable him to find ways to break with what is given, to develop and find solutions to his problems. Art is not committed to faithfully portraying reality, yet it does not emerge in a vacuum, it is deeply immersed in its cultural-historical context and is the expression of a set of values. It refers directly to our life, to the awareness of each viewer who receives it only and always alone. It is directed to the depths of our being (OSTROWER, 1959, 1981). It is in this process that it becomes liberating, because it finds in the human being something that is his own, that provokes the intellect and the emotions and goes deeper, reaches his subconscious, proposes Stanislavski (1982). By not referring to reality, art does not necessarily entail established thought patterns or cognitive relations, and even though the understanding of some signs may be common to individuals of the same culture, the relations and understandings will always be individual, due to the history, experiences, emotions, imagination, everything that involves each being. In this sense, art is directly related to the ideas of Vygotsky (1978), suggesting that art can serve as an artifact for the second stimulus, awakening man to new understandings, broadening horizons and offering a source for questioning and contradiction.

Stanislavski will be our inspiration and Vygotsky our intermediary to approach seemingly distant and even antagonistic worlds like Art and Administration. We boldly consider the latter all bureaucracy and the first one all feeling. 


\section{ENLIGHTENMENT - PROPOSED METHOD: THE CREATIVE SPIRIT AS STIMULUS FOR LEARNING}

The Moscow Art Theater grew out of Stanislavski's dissatisfaction with historicist theater, based on sociological research, loaded with technical resources, discipline, and pragmatism that was produced at the time (GUINSBURG, 2010). But Stanislavski worried about his own acting. While vacationing in Finland in 1906, reflecting on the causes of his dissatisfaction with the way he acted, he concluded that in his performances as an actor he was not giving the roles the vital flexibility and organicity that they were supposed to present. He had the perception that he acted out of the stereotypes he had accumulated within himself, which was not unlike the old conventionalism of the theater he criticized. In his own words:

I copied naiveté, but I was not naïve; I moved my feet quickly, but I did not perceive any inner hurry that might cause short quick steps. I had played more or less artfully, copying the outer appearances of experiencing my part and of inner action, but I has not experienced the part or any real necessity for action. (GUINSBURG, 2008, p. 311 - our translation).

In facing this problem, he concluded that he would need to experience those experiences in an emotionally deeper way, with psychological authenticity and true emotion. And this stance deeply links the works of Stanislavski and Vygotsky; the Russian term used by both is the same, perejivanie, meaning the experience of emotionally relevant cognitive experiences (GUINSBURG, 2008). It is not a futile emotionalism, but a deep, dramatic intensity of experiencing inwardly something that is external, of living intensely, of being whole in what is lived.

Our art, therefore, teaches us first and foremost to create consciously and rightly, for this is the best way of opening the way to the flowering of the unconscious, which is inspiration. The more consciously creative moments you have in your roles, the greater the possibilities of a flow of inspiration. (STANISLAVSKI, 1982, p. 43 - our translation)

Stanislavski's method stems from these concerns and from the experiences he went through with his theater company. In his book An Actor Prepares (1936), Stanislavski organizes the steps or sessions in each of the sixteen chapters ${ }^{2}$. In this first approach, we choose the chapters: II) When acting is an art; III) Action; IV) Imagination - because of space limitations and the need to conceptualize the bases for the development of a method for OL. Stanislavski's method is quite rich and offers many possibilities for connections with Organizational Learning. As this article is about a first approximation, our focus is on approaching some initial aspects of a learning method based on Stanislavski's ideas, certain

2. In his book An Actor Prepares, Stanislavski organizes the steps or sessions in sixteen chapters, namely: I) The first test, II) When acting is an art, III) Action, IV) Imagination, V) Concentration of attention, VI) Relaxation of muscles, VII) Units and Objectives, VIII) Faith and a sense of truth, IX) Emotion memory, X) Communion, XI) Adaptation, XII) Inner motive forces, XIII) The unbroken line, XIV) The inner Creative State, XV) The super-objective and $\mathrm{XVI}$ ) On the threshold of the subconscious. 
that this is only a sketch, but relevant, considering the distance and lack of studies involving art and organizational learning. Thus, we present a proposed method for organizational learning backed by the concepts in Stanislavski's book An Actor Prepares.

\subsection{WHEN WORKING IS ART! (ASKING)}

To carry out work as an art means to intentionally and consciously put oneself as a whole into the lived experiences of everyday life. Not ignoring the feelings, the emotions; on the contrary: putting them in what you do. Let us think of a method for organizational learning: what Stanislavski and Vygotsky assert then is that if we are to produce something that has relevance to ourselves and to the world, we cannot do it mechanically, dissociating it from who we are and how we understand the world. This discussion invites us to think, departing from the work, and therefore, from the organization, about a more integral, creative way of living this space.

It often seems that we have the ability to live completely separate lives: the professional life takes place in one sphere, and the personal life in another one. It seems that we are able to completely separate who we are from what we do. However, this schizophrenic posture, besides being impossible in practice, deprives our work of meaning in such a profound and alienating way that it can muffle it to the point of putting out the creative flame that burns inside the human being. The capitalist system and the specialization of labor collaborate in this process, but when we think of a spiritual human being, we understand that his capacity is not enclosed in the system, in the context, in the structure. We believe that he has the capacity to extrapolate that which is imposed onto him.

Even if one tries to live this dichotomous life, at some point these lines will intersect, and in that moment, there will be the possibility of development. Often this moment occurs during an outpouring of emotions, when we can no longer hold the internal pressure, and then, what we really are comes to the surface. When that happens, we truly connect with that moment and everything we are shows there. The problem is that neither the organization nor ourselves know how to deal with this, and we often miss the opportunity to use that emotion to expand and to develop.

The first point of the method proposes that we do this intentionally, that we free our emotions, let what we are feeling flow into the activity, so that, through it, we can resignify and shape our practice. It is about consciously reflecting on our emotions and allowing them to indicate goals that are worth pursuing. Hodder (2016) explains that emotions are genuine and significant; he calls them instances of intentionality, thus revealing our real intentions. This process will not always bring benefits from the progressive point of view, nor will this process always succeed, increase performance, maximize profits. It can, on the contrary, generate conflicts, resignation requests, painful changes, crises. Although there is little consensus, there is a common understanding that emotions can have positive and negative effects on people and organizations (HODDER, 2016; VINCE, GABRIEL, 2011).

The challenge for organizations is to assimilate these processes in order to allow and encourage people to experience their work more authentically. On the other hand, organizations can also benefit from this process, becoming more authentic and naturally different 
from others. In this way, the harrowing search for market differentiation could take place in a more natural way, because, as human beings, we are naturally different, heterogeneous, unique.

Art itself, as an expression of the uniqueness and subjectivity of the human being, free from the logic of the cultural industry, represents a medicine and a cure for this dichotomy. Medicine because even as spectators, as observers, art can touch us to the point of raising questions, worries, unmasking the lies we believe in, revealing the structures that bind us.

I cannot insist enough on this point: art deals with values, not information. This explains why art must be created by the totality of man, being directed, in turn, to the totality of man, composed simultaneously by his intellect and his emotions. No judgment can exist in a vacuum. It will always be related to and will depend on defined, limited, unique situations that never involve a mechanical repetition. (OSTROWER, 1959, p. 2 - our translation)

Art also presents itself as a cure, because once we live as artists, as the spiritual beings we are, we will never be able to live in the perspective of the finite, the limitations of what we can see of reality, the pragmatic and mechanical void, the utility of the remuneration exchange. We will be impelled to transcend and signify, and, thus, to work as (if we were creating) art.

So, in the artist who tries to articulate the spirit of its time we should not see a soothsayer who emits forebodings about some vague future, but the man who tries to penetrate deeply into the essence of his own life, gaining consciousness in doing so. And it is this process of awareness that the spectator participates in, according to the particular situations in which he finds himself. (OSTROWER, 1959, p. 2 - our translation)

This is not a life alienated from reality, in an illusory world. It is not a matter of denying capitalism, of pretending that practical life does not exist, that making money is unnecessary, that the way out is to take refuge in a monastery, in a cave or in the forest. On the contrary, the proposal is that we should be so aware of our livese, of our history, of the social context, of the time in which we live and of our humanity, that based on such awareness we can let ourselves to be touched by a spiritual force that allows us to see this reality as possibilities of being what we wish to be.

If we are not accustomed to experiencing our own emotions and feelings, if we are not encouraged to access them, art itself can serve as an artifact to raise the questions that lead us to our essence. "Consuming" art can be a way to awaken the spiritual force that leads us to experience all walks of life in a more integral way; can be a way to experience work as art.

This point of the method presents itself as a transversal line that runs through the whole method; each point is imbued with this understanding and ontological posture. 


\subsection{ACTION (EXPERIENCING)}

The action starts from a spiritual attitude, that is, it is directly related to the first step of this method. If we put ourselves spiritually into what we are living, our actions will reflect that. Then, we will be impelled to interfere, to propose different solutions, to question directions, to use our emotions and not to hide them. This will require the willingness of the organization to handle conflicts and contradictions dialectically, and will require the individual to come out of its hiding place and expose himself. It is in the action that spirituality is concretized. "[...] in theater all action must have an interior justification, it must be logical, coherent and real" (STANISLAVSKI, 1982, p. 73), that is, the process of placing oneself into what is being lived is a conscious first step in which reflection on emotions leads us to coherent actions.

Similarly, learning also takes place in practice; it will never be mere lucubration, it gains meaning in action. This second step tries to objectively and concretely externalize what we believe in. It is in the production of work that creativity surfaces; it is in the action that spirituality is concretized. "The creative potential of man is accomplished within his own productivity" (OSTROWER, 1959, p. 1).

In the method, when Stanislavski (1982) approaches the subject of action, he conditions the actions both to an earlier posture of goals and wholeness seen in the previous step, and to an imaginative projection, which entails an assumption, which refers to the "what if". It is a resource of supposition that serves as a trigger for imagination. For example: "What if a monster entered through this door". This assumption incites the imagination, "[...] if acts as a lever that helps us to get out of the world of facts, lifting us into the realm of imagination" (STANISLAVSKI, 1982, p. 73). This brings us to the next step of the method, the imagination.

\subsection{IMAGINATION (RESPONDING)}

Vygotsky (2009) also devoted himself to the theme of imagination; he studied how imagination occurs in children and how the social context interferes with how they construct their fantasies and imagination. He makes it clear that imagination has a positive role as a resource for the expansion of knowledge and for human development. Imagination touches reality in four ways: through a person's accumulation and richness of experiences; by means of its relation with time in a process of incubation and transformation; in the emotional relationship present in the imaginative process; and through crystallized fantasy - the ultimate and final moment of an imaginative process. He demystifies the idea that children would be more imaginative than adults on the grounds that their repertoire, in terms of lived experiences, is smaller and, therefore, they would be less capable of making connections. In Vygotsky's (2009) conception, imagination has the power to change reality and, consequently, is fundamental in the personal and social development.

Stanislavski considers imagination extremely important to the creation process of the actor. Without imagination, it is impossible to create. Vygotsky and Stanislavski regard imagination as innate, they believe that it is present in all human beings and that, although it 
may be "endowed with its own initiative" (STANISLAVSKI, 1982, p. 90) in some people who develop it effortlessly, it can be stimulated or held back in each and every one. Here, again, art is presented as medicine; evidently, people who have been stimulated since childhood may have an easier time in developing imagination and creativity, but we have the capacity to stimulate our imagination and art can be a stimulus for that to happen. Faria and Alencar (1996) made a list of stimuli and barriers to creativity in the work environment, and the ones that stand out are the support from the boss and colleagues and the freedom to risk new possibilities. Organizations can stimulate or inhibit imagination and creativity.

Imagining is also answering! In Stanislavski's method, imagination caused by "what if" questions arises in response to the questions raised in the first point of the method. To answer a question, we need to think, to imagine a situation that will serve as an answer to that question. To imagine is to create!

In the process of learning and development, imagination and creation are fundamental in the search for solutions; they are an expression of the awakening of man and reflect his most intimate understandings of the world. Everything that man is, is expressed in creation; creation is the representation of his spirituality.

The first draft of this method closes an Ask> Experience>Respond cycle. In other words, by putting oneself into the activity as a whole person, in awakening his spirituality, man constructs questions about what he is experiencing, questions that relate to the meanings and goals he has in relation to the activity. The first step then is to ASK. The second step is to experience, in the activity, what one believes; it is to experience the dilemma, the contradictions; to externalize the restlessness, to problematize, to strain, to stretch, while one can EXPERIENCE. The third step that closes this first cycle is to imagine solutions, to expand the possibilities; to use art as an artifact (the second stimulus proposed by Vygotsky), is to extrapolate the limits of structures and of the human being himself; it means to go beyond what is given to find answers. Imagining is RESPONDING.

The hexagon refers to the first step of the method "when working is an art!". The idea is that the person, awakened by art, becomes an ARTIST and ASKS about his individuality, seeking to align his emotions, his experiences, his spirit and his body, that is, his full self, with his work. In this step, the person takes, to his professional activity, all the aspects that make up his totality. Hence, the hexagon appears smaller between the other circles representing the other steps. That is, the first step is essential and is present in constant dialectics with the ACTION and IMAGINATION that represent the following steps.

The circle with the label ACTION represents the second step, when the worker sees himself as an artist and takes his individuality to his work. The arrows that leave the center represent that the individual, when positioning himself as an ARTIST, will also take, to the activity, his values, his contradictions, his conflicts, his anxieties and his dilemmas. This causes the individual to put himself fully into the action. It is when the integrality of the being is experienced in the work that his values, contradictions, anxieties and dilemmas PROBLEMATIZE, STRESS and STRETCH the meanings and the very action, the very practice of work, and the act of stressing takes him to the third step.

The third step is represented by the circle labeled IMAGINATION. When the values of the individual reveal problems, they stretch the action and allow to extrapolate the ordi- 
nary. The arrows that now extrapolate the circle represent this break, this act of going beyond the ordinary. It means creating new possibilities, finding new solutions, learning, using art as an artifact of this creative overflow. The central idea is that it is through this expansion of the subject to the activity that one can extrapolate the known and learn new ways. Learning, creativity and innovation become possible in a continuous and organic process. The longer arrows around the figure represent this continuous dynamic.

Although we have used the word steps, we use it from the perspective that learning is a journey. Subsequently, we can explore this point in Stanislavski's method that deals with a continuous line, linking the past, the present, and the future, that states that there are several lines that can be restarted whenever the questions are changed.

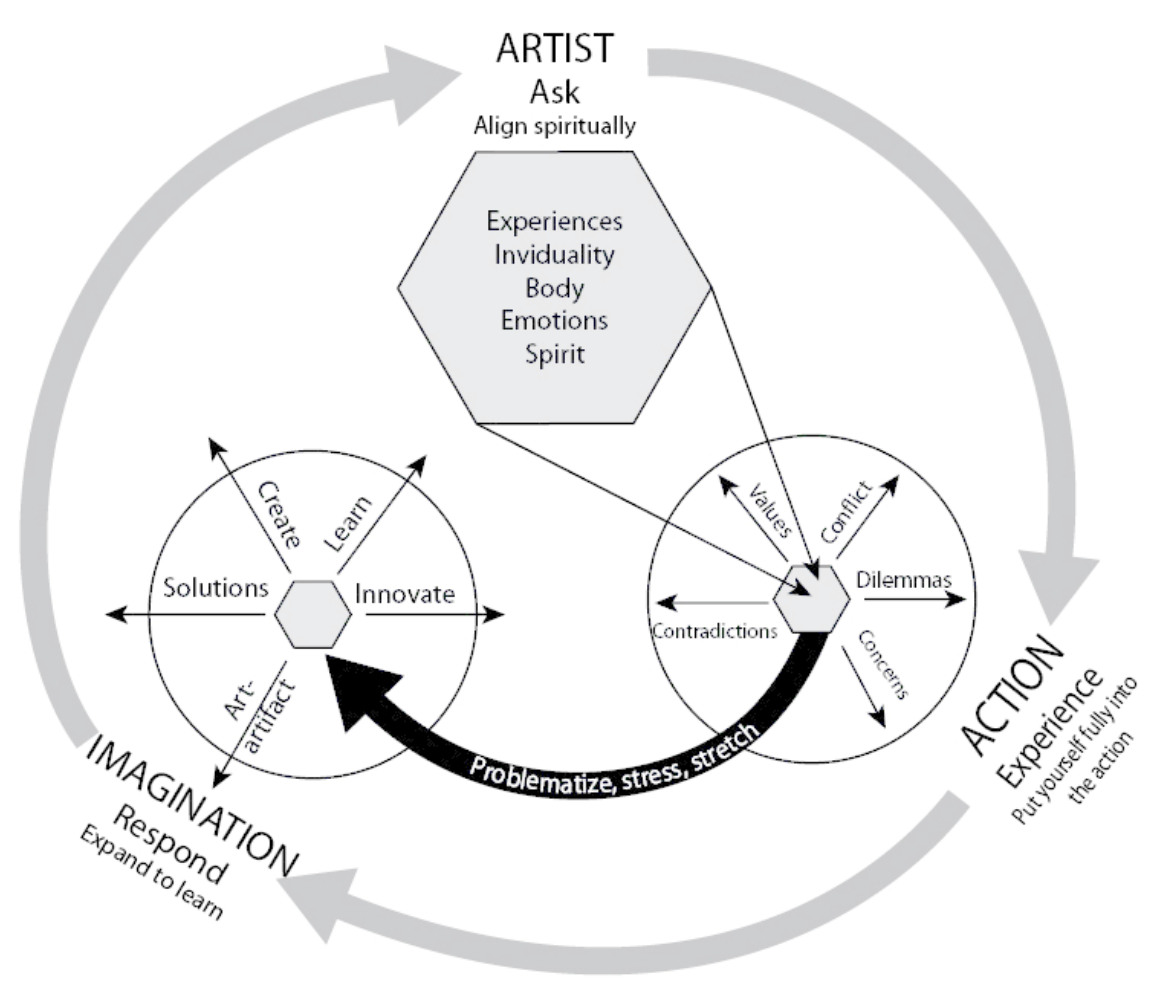

Figure 1 - Cycle of the proposed learning method

Source: Prepared by the authors.

In this article, we do not reach the apex of Stanislavski's method of reaching the subconscious (Chapter XVI of the book An Actor Prepares) as the deepest and most creative point of the human being, from which, in fact, all of his creative essence flows. We did not do this because this was the first approach of the method and because of the importance of knowing how to understand the human being in his entirety, as a spiritual being; this was a first movement so that further studies can deal with other steps of the actor's preparation based on Stanislavski. Other areas have long been devoted to such an understanding, but utilitarianism tends to stifle such approaches. 


\section{THE LIGHTS SWITCH OFF}

In this article, we aimed to connect the actor preparation method of Stanislavski to OL, specifically to Vygotskian theories, seeking to advance in the theoretical understanding and in the construction of a method for the expansion of the human being as a spiritual being also in the organizational environment. The method presented herein fulfills this function by introducing several points of contact across existing theories, and by proposing to advance in some others.

In this sense, referring back to the dialectical view of the Russian tradition, it presents congruence and advances to theories such as the CHAT, since it understands that the subject, by putting himself into the activity, uniting his individuality, his body, his emotions, experiences, and from the contribution of Stanislavski can have a spiritual coherence. This spiritual coherence comes from the essence of the subject, which leaves what he feels flowing into the activity and thereby opens the possibility of re-signification and shaping the practice. It is in this process of experiencing practice in an emotionally profound (perejivanie), intuitive, intense way that the subject can ascend from the abstract to the concrete, expanding his previous reality and liberating his creative and transforming potential of himself and the society around him.

The three steps proposed by the method are possible to be experienced in organizations. However, it requires effort on both sides, the individual himself and the leadership of organizations. At the same time that the human being in the organization seeks to align spiritually, the organization could offer habitual, constant and planned spaces of encouragement for individuals to place themselves fully in the activity they perform (step 1). In this way, the individual would be impelled to bring his dilemmas, values, and restlessness into the activity; the organization would need to give space and be able to deal with these moments of "discomfort" (step 2), knowing, however, that it is this discomfort that allows both human beings and organizations to expand and learn, to find new creative paths, new solutions, and actually experience deep innovations. In practice, it is not a question of humanizing organizations, but of living human relations in a more humanized way.

We also consider it important to highlight some of the discussions and understandings that we have developed throughout this article to enlighten certain issues that we believe are pertinent to the agenda of discussions in the field of OL.

The perception of the human being: OL possesses the possibility of transforming reality; a possibility that stems from the subject, who appropriates knowledge, analyzes reality and transforms his surroundings, and, consequently, history. However, a word of caution is in order: in the capitalist society in which we live, this autonomy could be just a false idea created for specific purposes, such as a greater involvement and commitment of the subject to his activity. Despite the care we are suggesting in relation to such autonomy, in our view, perhaps the greatest contribution we make to this discussion is that what is missing, in these theories, is the understanding of man as an integral being; one that also comprises his emotions, spirituality and body. Our proposal in this article was to raise this question and discuss the importance of considering the integrality of the human being, of verifying that he can be touched in his spirituality in several ways, especially by art, as we 
suggest. The understanding and conceptualization of man as a spiritual being, and that spirituality that involves work, needs to be deepened and deserves attention in new studies.

Emotions: in this study, we discuss emotions as part of the integrality of the human being. We deal with the need for the subject to align, considering his emotions in his work as indicators and motivators of what is really important to him and from which learning and innovation can emerge. We believe that this is an important point for future research within $\mathrm{OL}$, and OE. We emphasize our interest in distinguishing the use of emotions as an instrument of power and manipulation for institutional interests (MOISANDER; HIRSTO; FAHY; 2016), from their understanding as being relevant to the integrality of the human experience in organizations (WADDOCK, 1999; FLAM, 1990, REASON, 1993).

Art as Stimulus: when Veresov (2010) uses the concepts of development possibilities of Vygotsky (1978) (Real-Potential, ZPD), he points to the importance of artifacts (tools) and signs (meanings) for development to take place from Real to Ideal. Cole and Engeström (2001) also point to the role of artifacts in the development process. Our method proposes art as a stimulus in two perspectives: 1) Art as Artifact: the consumption of art as an artifact for the awakening of spirituality, that is, as a stimulus for the healing of a state of alienation. And a second aspect, 2) Art as a Sign: as a process, as a way of putting oneself into the world, especially in relation to work, that is, art as meaning making or re-signifying the relationship with work. Art has been retrieved and valued in recent studies in OE (BARRY, 2008; PÄSSILÄ; OIKARINEN, 2014; VERA; CROSSAN, 2004), and the depth of Stanislavski and the Actor Formation method is still a rich source for future studies in OL.

The leading activity as part of what constitutes the human being: OL has worked with the concept that the leading activity of the subject is that which organizes his daily life (COLE; ENGESTRÖM, 2001). In this context, it seems relevant to think about work as part of what constitutes the spirituality of the human being. When we talk about man as a spiritual being, we recover an important point of the Protestant Reformation that, as Weber (2004) shows us, ends up not being assimilated by society: the idea that both work and prayer constitute aspects of spirituality (ora et labora). This sense extends the importance of work as the leading activity of adult life and allows us to understand its meanings beyond the instrumental aspects, considering it as constituent of identity and individuality. This is another topic that seems fruitful for further research.

Based on Barry (2008), we also suggest that the studies advance theoretically and empirically. The method we present could be used in small businesses where the owners are part of the main activity of the organization, or in new organizations such as Startups. It could also be used at managerial level, presented to employees and work teams. Additionally, it could be used as a tool in the construction of new organizational arrangements in periods of beginning new business or even in times of organizational changes.

Finally, we believe that it is necessary to overcome the Cartesian division, the separation of body, mind and spirit for a more comprehensive understanding of human experiences in organizations. If we want to build new possibilities for man's relationship with work, a relationship that encompasses his spirituality, we need to envision new organizations. 


\section{REFERENCES}

AdORNO, T. W. Os Pensadores: Textos Escolhidos. São Paulo: Nova Cultural, 1999.

ANTONELLO, C.S.; GODOY, A.S. Aprendizagem organizacional e raízes da polissemia. In: ___ (eds.). Handbook de Aprendizagem Organizacional. Porto Alegre: Bookman, 2011.

BARRY, D. The Art of... In: BARRY, D.; HANSEN, H. (eds.). The SAGE handbook of new approaches in management and organization. London: Sage, 2008.

BITENCOURT, C. C; AZEVEDO, D. O futuro da aprendizagem organizacional: possibilidades e desafios. Revista de Administração de Empresas, v. 46, p. 110-112, 2006. [Edição Especial].

CAMPBELL, C. On understanding modern consumerism and misunderstanding the romantic ethic thesis: A reply to Boden and Williams. Sociology, v. 37, n. 4, p. 791-797, 2003.

CASSANDRE, M. P.; GODOI, C. K. Metodologias intervencionistas da teoria da atividade histórico-cultural: abrindo possibilidades para os EO. RGO - Revista Gestão Organizacional, v. 6. Edição Especial, 2013.

COLE, M.; ENGESTRÖM, Y. Cultural-historical approaches to designing for development. In: ROSA, A.; VALSINER, J. (eds.). The Cambridge Handbook of Sociocultural Psychology. Serie: Cambridge Handbook in Psychology. UK: Cambridge University Press, 2001, p. 484507.

ELKJAER, B. Organizational learning: the third way. Management Learning, v. 35, n. 4, p. 419-434, 2005.

ENGESTRÖM, Y. Activity theory and individual and social transformation. In: ENGESTRÖM, Y.; MIETTINEN, R.; PUNAMÄKI, R. L. (eds.). Perspectives on activity theory. UK: Cambridge University Press, 1999, p. 19-38.

FARIA, F. B. F.; ALENCAR, M. L. S. A. Estímulos e barreiras à criatividade no ambiente de trabalho. Revista de Administração, v. 31, n. 2, p. 50-61, 1996.

FLAM, H. The emotional 'Man' and the problem of collective action. International Sociology, v.5, n.1, p. 39-56, 1990.

FOUCAULT, M. Vigiar e punir. São Paulo: Leya, 2014.

GHERARDI, S. Practice-Based Theorizing on Learning and Knowing in Organizations. Organization, v. 7, n. 2, p. 211-223, 2007.

GUINSBURG, J. Stanislavski, Meierhold \& Cia. São Paulo: Perspectiva, 2008.

. Stanislávski e o Teatro de Arte de Moscou. São Paulo: Perspectiva, 2010.

HODDER, R. Emotion, Organization and Society. Society, v. 53, n. 4, p. 425-434, 2016.

KAHNWEILER, W.; OTTE, F. L. In search of the soul of HRD. Human Resource Development Quarterly, v. 8, n. 2, p. 171-181, 1997. 
LINCOLN, Y.S.; GUBA, E.G. Controvérsias paradigmáticas, contradições e confluências emergentes. In: DENZIN, N. K.; LINCOLN. Y. S. (orgs.). 0 planejamento da pesquisa qualitativa: teorias e abordagens. 2. ed. Porto Alegre: Artmed, 2006.

MARX, K. 0 capital: livro 1. Rio de Janeiro: Civilização Brasileira, 1968.

MOISANDER, Johanna K.; HIRSTO, Heidi; FAHY, Kathryn M. Emotions in institutional work: A discursive perspective. Organization Studies, v. 37, n. 7, p. 963-990, 2016.

OSTROWER, F. A criatividade na Educação In: PEREIRA, M.L.M. A Arte como Processo na Educação. Rio de Janeiro: FUNARTE, 1981.

Arte e Espectador. Aula encerramento do Curso de Composição e Análise Crítica. Museu de Arte Moderna: Rio de Janeiro, 1959. Available in: <https://faygaostrower.org.br/ livros-e-videos/artigos-e-ensaios/arte-e-espectador> . Accessed in: 20/04/2016.

PÄSSILÄ, A.; OIKARINEN, T. Research-based Theater as a Facilitator of Organizational Learning. In: ANTAL, A.B.; MEUSBURGER, P.; SUARSANA, L. Learning Organizations. Extending the field, knowledge and space. v. 6. Springer: Netherlands, 2014, p. 203-221.

QUEROL, M. A. P.; CASSANDRE, M. P.; BULGACOV, Y. L. M. Teoria da Atividade: Contribuições Conceituais e Metodológicas para o Estudo da Aprendizagem Organizacional. Gest. Prod., v. 21, n. 2, p. 405-416, 2014.

RAMOS, Alberto Guerreiro. Modelos de homem e teoria administrativa. Revista de administração pública, v. 18, n. 2, p. 3-12, 1984.

REASON, P. Reflections on sacred experience and sacred science. Journal of Management Inquiry, v. 2, n. 3, p. 273-283, 1993.

RECKWITZ, A. Toward a theory of social practices: a development in culturalist theorizing. European Journal of Social Theory. n. 5, v. 2, p. 243-263, 2002.

SANNINO, A. Activity theory as an activist and interventionist theory. Theory \& Psychology, v. 21, n. 5, p.1-27, 2011.

STANISLAVSKI, C. A preparação do ator. Rio de Janeiro: Editora Civilização Brasileira, 1982.

VERA, D.; CROSSAN, M. Theatrical improvisation: Lessons for organizations. Organization Studies, v. 25, n. 5, p. 727-749, 2004.

VERESOV, N. Introducing cultural historical theory: main concepts and principles of genetic research methodology. Cultural-Historical Psychology, v. 4, p. 83-90, 2010.

VIGOTSKI, L.S. Imaginação e criação na infância. São Paulo: Ática, 2009.

VINCE, R; GABRIEL, Y. Organizations, Learning, and Emotion. In: Easterby-Smith, M; Lyles, M. A. (Eds). Handbook of Organizational Learning and Knowledge Management. United Kingdom: John Wiley \& Sons, p.331-348. 2011

VYGOTSKY, L. Interaction between learning and development. In: COLE, M.; JOHN-STEINER, V.; SCRIBNER, S.; SOUBERMAN, E. (eds.). Mind and Society: the development of higher psychological processes. Cambridge: Harvard University Press, p. 19-91, 1978. 
WADDOCK, S. A. Linking community and spirit: a commentary and some propositions. Journal of Organizational Change Management, v. 12, n. 4, p.332-345, 1999.

WEBER, M. Economia e Sociedade. v. 1. Brasília: Ed. UnB, 1998.

A ética protestante e o espírito do capitalismo. São Paulo: Cia das Letras, 2004.

WEDEKIN, L. M.; ZANELLA, A. V. L. S. Vigotski e o ensino de arte: "A educação estética" (1926) e as escolas de arte na Rússia 1917-1930. Pro-Posições, v. 27, n. 2, 2016, p. 155-176.

WEICK, K. E.; WESTLEY, F. Aprendizagem organizacional: confirmando um oximoro. In: CLEGG, S.; HARDY, C.; NORD, W. R. (org.). Handbook de Estudos Organizacionais: ação e análise organizacionais. v.3, São Paulo: Atlas, 2004, p. 361-388.

Submission date: 06/11/2016.

Approval date: 05/19/2018.

Note: you can find this paper in Portuguese at http://www.revistaoes.ufba.br. 